\title{
First cytotoxic, genotoxic, and antigenotoxic assessment of Euterpe oleracea fruit oil (açaí) in cultured human cells
}

\author{
E.S. Marques ${ }^{1}$, M.S.F. Tsuboy ${ }^{2}$, J.C.T. Carvalho ${ }^{3}$, P.C.P. Rosa ${ }^{4}$, F.F. Perazzo ${ }^{5}$, \\ I.O.M. Gaivão ${ }^{6}$ and E.L. Maistro ${ }^{1,7}$ \\ ${ }^{1}$ Programa de Pós-Graduação em Biologia Geral e Aplicada, \\ Instituto de Biociências, Universidade Estadual Paulista, Botucatu, SP, Brasil \\ ${ }^{2}$ Departamento de Biotecnologia, Faculdade de Ciências e Letras, \\ Universidade Estadual Paulista, Assis, SP, Brasil \\ ${ }^{3}$ Laboratório de Pesquisa em Fármacos, Centro de Ciências Biológicas e da Saúde, \\ Colegiado de Farmácia, Universidade Federal do Amapá, Macapá, AP, Brasil \\ ${ }^{4}$ Faculdade de Ciências Médicas, Universidade Estadual de Campinas, \\ Campinas, SP, Brasil \\ ${ }^{5}$ Departamento de Ciências Exatas e da Terra, Instituto de Ciências Ambientais, \\ Químicas e Farmacêuticas, Universidade Federal de São Paulo, \\ Diadema, SP, Brasil \\ ${ }^{6} \mathrm{CECAV}$ and Department of Genetics and Biotechnology, \\ Trás-os-Montes and Alto Douro University, Vila Real, Portugal \\ ${ }^{7}$ Departamento de Fonoaudiologia, Faculdade de Filosofia e Ciências, \\ Universidade Estadual Paulista, Marília, SP, Brasil \\ Corresponding author: E.L. Maistro \\ E-mail: edson.maistro@marilia.unesp.br \\ Genet. Mol. Res. 16 (3): gmr16039700 \\ Received April 12, 2017 \\ Accepted June 7, 2017 \\ Published August 17, 2017 \\ DOI http://dx.doi.org/10.4238/gmr16039700
}

Copyright (C) 2017 The Authors. This is an open-access article distributed under the terms of the Creative Commons Attribution ShareAlike (CC BY-SA) 4.0 License.

ABSTRACT. Euterpe oleracea Mart., popularly known as "açaí", is a tropical fruit from the Amazon region where it has considerable economic importance. Açaí has been used as food and for several medicinal purposes. Despite the widespread use of this fruit, there is

Genetics and Molecular Research 16 (3): gmr16039700 
a lack of data regarding the safety of using this fruit oil exclusively. Therefore, we evaluated the in vitro cytotoxic, genotoxic, and antigenotoxic effects of E. oleracea fruit oil (EOO) in cultured human lymphocytes (non-metabolizing cells) and HepG2 cell line (human hepatoma) (metabolizing cells) by using MTT, comet, and micronucleus assays. A wide range of EOO concentrations was tested with a preliminary MTT assay, which allowed selecting five concentrations for comet and micronucleus assays: 2.5, 10, 100, 500, and $1000 \mu \mathrm{g} / \mathrm{mL}$. The results showed that none of the EOO tested concentrations presented cytotoxic effects. The genotoxic assessment revealed an absence of significant DNA and chromosome damage in human lymphocytes and HepG2 cells but did not show chemoprotection against the DNA damage induced by methyl methanesulfonate and benzo[a]pyrene, used as DNA-damaging agents.

Key words: Açaí oil; Arecaceae; Comet assay; HepG2 cells; Micronucleus test

\section{INTRODUCTION}

Cancer is still one of the most worrying human health problems, is responsible for roughly one-quarter of global deaths, as well as has the most devastating economic impact of any cause death in the world. The interventions for cancer prevention and control are done through policies of the primary prevention, early detection, diagnosis, treatment, and palliative care (WHO, 2002; UICC, 2008; Rocco et al., 2015).

Considering that mutational events are involved in the first steps of carcinogenesis, if the damage is removed by repair enzymes before it can interfere with the process of DNA replication and introduce mutations, it will decrease cancer incidence (Bauer et al., 2015). The scientific community has been focusing on the study of compounds in the diet that may protect DNA, not forgetting the obligatory assessment of the genotoxic potential of these compounds.

Euterpe oleracea Mart. is a plant from Arecaceae family and its fruit is commonly known as "açaí" or "açaí berry". The açaí fruit has a vital economic importance in the South America, being commercialized as frozen pulp, juice, or wine (Murrieta et al., 1999). This fruit is also used in folk Brazilian medicine to treat anemia, diarrhea, malaria, pain, inflammation, hepatitis, and kidney diseases (Leão et al., 2007; Souza et al., 2011; Caetano et al., 2014; de Bem et al., 2014; Vásquez et al., 2014). Specific açaí fruit oil therapeutic potentials regarding anti-inflammatory, antinociceptive, and antidiarrheic activities were reported (Plotkin and Balick, 1984; Favacho et al., 2011).

Our previous chemical characterization of the açaí fruit oil, used in the present study, has shown the presence of vanillic, palmitic, $\gamma$-linolenic, linoleic, oleic, cinnamic, caffeic, protocatechuic, ferulic, and syringic acids, and the flavonoids quercetin and kaempferol rutinoside as main constituents (Marques et al., 2016). Favacho et al. (2011) also reported the presence of the fatty acids, oleic, palmitic, and palmitoleic compounds as the major constituents of the açaí fruit oil. According to Del Pozo-Insfran et al. (2004), the presence of bioactive substances, such as phenolic acids, flavonoids, and anthocyanins, attributes antioxidant properties and antitumorigenic potential to this fruit.

Genetics and Molecular Research 16 (3): gmr16039700 
Considering the significant economic importance of E. oleracea fruit as a functional food, its phytotherapeutic potential, and lack of studies involving the genetic toxicity exclusively of the fruit oil in human genetic material, as well as its potential for chemoprotection against DNA-damaging agents, the aim of this study was to investigate the cytotoxic, genotoxic, and antigenotoxic effects of E. oleracea fruit oil (EOO) in human lymphocytes and HepG2 cells through the thiazolyl blue tetrazolium bromide (MTT), comet assay, and cytokinesis-block micronucleus (CBMN) assays.

\section{MATERIAL AND METHODS}

\section{Plant material}

The EOO (Arecaceae family) was kindly provided by the Açaí do Amapá AgroIndustrial Ltda. (Sambazon), Macapá city, Amapá State, Brazil. The extraction method consisted of a standardized method used by the company, which cannot be published, because of patent protection. The phytochemical characterization of the oil was performed by our research group and published in Marques et al. (2016).

\section{Chemical agents}

Dulbecco's modified Eagle's medium (DMEM) (Gibco) was used with HepG2 cells, and RPMI-1640 medium (Gibco) was used with human lymphocytes. Methyl methanesulfonate (MMS) (Aldrich, CAS number 66-27-3) and benzo[a]pyrene (BaP) (Sigma-Aldrich) were used as the positive control, due to its potential for DNA damage, recognizable in the comet and micronucleus assays. The other main chemicals were obtained from the following suppliers: trypsin (Sigma-Aldrich), phytohemagglutinin (PHA) (Sigma-Aldrich), cytochalasin-B (SigmaAldrich), normal melting point (NMP) agarose (Invitrogen), low melting point (LMP) agarose (Invitrogen), fetal calf serum (Gibco), ethylenediaminetetraacetic acid (EDTA) (Merck), Triton X-100 (J.T. Baker), trypan blue (Sigma-Aldrich), MTT/ethidium bromide (Sigma), dimethyl sulfoxide (DMSO) (Sigma-Aldrich), Giemsa (Synth), and Histopaque-1077 (SigmaAldrich). EOO was dissolved in 1\% DMSO.

\section{Culture of human cells}

In this study, human peripheral blood lymphocytes (PBL) (non-metabolizing cells) collected from 3 healthy ( 2 males and 1 female) non-smoking volunteers aged 18 to 27 years old, and a human hepatoma cell line (HepG2) having phase 1 and 2 enzymes (metabolizing cells) (Hewitt and Hewitt, 2004) were used. HepG2 cells were obtained from the Cell Bank of Rio de Janeiro, Brazil. Donors of PBL provided written informed consent at the time of donation for the use of their blood sample in this study. The Ethics Committee of the Universidade Estadual Paulista (UNESP), in Marília town, Brazil, approved the present study in December 2012 (protocol No. 0603/2012).

The PBL were cultivated in RPMI (Roswell Park Memorial Institute) culture medium, at $37^{\circ} \mathrm{C}, 5 \% \mathrm{CO}_{2}$, and $95 \%$ relative humidity and the HepG2 cells were cultivated in DMEM supplemented with $10 \%$ fetal bovine serum (Gibco) and antibiotics (Gibco), at $37^{\circ} \mathrm{C}, 5 \% \mathrm{CO}_{2}$, and $95 \%$ air in a humidified incubator.

Genetics and Molecular Research 16 (3): gmr16039700 


\section{MTT assay}

The MTT test (CAS No. 298-93-1; Sigma) was performed with leukocytes and HepG2 cells, according to the protocol of Mosmann (1983), with some modifications. In each well of a 96-well plate, $2 \times 10^{4}$ cells were seeded. After a period of $24 \mathrm{~h}$ for cell stabilization, the medium was removed and $200 \mu \mathrm{L}$ culture medium plus $1 \%$ DMSO (without serum) was added to the control and culture medium without serum plus the test mixture and 1\% DMSO (diluent). The concentrations of EOO tested were 0.1, 0.5, 1, 2.5, 5, 10, 25, 50, 100, 250, 500, 800 , and $1000 \mu \mathrm{g} / \mathrm{mL}$. Incubation was for 4 and $24 \mathrm{~h}$, then the test substance was removed, and $150 \mu \mathrm{L}$ MTT solution $(5 \mathrm{mg} / \mathrm{mL})$ was added. The plate was incubated for $4 \mathrm{~h}$, in an incubator at $37^{\circ} \mathrm{C}$. After this period, the MTT solution was discarded and, in each well, 100 $\mu \mathrm{L}$ DMSO was added. The plates were then read in the spectrophotometer with a microplate reader (Epoch-Biotech) with a 540-nm filter.

\section{Comet assay}

The comet assay was performed according to Tice et al. (2000) in PBL and HepG2 cell line. First, the preparation of slides was carried out precoating with a thin uniform layer of NMP agarose. Approximately $2 \times 10^{5}$ cells per well were put on a 24-well plate and incubated for $24 \mathrm{~h}$ for cell attachment (in the case of HepG2). The açaí oil treatment was performed using $2.5,10,100,500$, and $1000 \mu \mathrm{g} / \mathrm{mL}, 150 \mu \mathrm{M}$ positive control MMS, and the negative control was the own culture medium used in the respective cells, all incubated for $4 \mathrm{~h}$. To evaluate the antigenotoxic potential of EOO, the cells were pre-incubated for $1 \mathrm{~h}$ at $37^{\circ} \mathrm{C}$ with $150 \mu \mathrm{M}$ MMS. After this incubation period, the cells were exposed, for $4 \mathrm{~h}$, to the EOO concentrations. Concentrations were selected based on the absence of toxicity in trypan blue exclusion test (data not shown) as well as MTT assay. After a 4-h treatment, cells are removed and placed with 120 $\mu \mathrm{L}$ LMP agarose on the precoating microscope slide. Slides were immersed in a vat with cold, freshly prepared lysis solution consisting of $89 \mathrm{~mL}$ of a stock solution $(2.5 \mathrm{M} \mathrm{NaCl}, 100 \mathrm{mM}$ EDTA, $10 \mathrm{mM}$ Tris, $\mathrm{pH}$ set to 10.0 with $8 \mathrm{~g} \mathrm{NaOH}, 890 \mathrm{~mL}$ distilled water, and $1 \%$ sodium lauryl sarcosine), plus $1 \mathrm{~mL}$ Triton X-100 (Merck) and $10 \mathrm{~mL}$ DMSO (Merck). Slides were left for 1 $\mathrm{h}$ for lysis. The slides were transferred to electrophoresis box, positioned at the anode end, and covered with alkaline buffer $(\mathrm{pH}>13)(300 \mathrm{mM} \mathrm{NaOH}$ and $1 \mathrm{mM}$ EDTA solution), where the slides remained for $20 \mathrm{~min}$, for DNA denaturation followed electrophoresis in an ice bath $\left(4^{\circ} \mathrm{C}\right)$ for $20 \mathrm{~min}$ at $25 \mathrm{~V}$ and $300 \mathrm{~mA}(0.722 \mathrm{~V} / \mathrm{cm})$. Slides were then submerged in a neutralization buffer ( $0.4 \mathrm{M}$ Tris-HCl, $\mathrm{pH} 7.5)$ for $15 \mathrm{~min}$, dried at room temperature, and fixed in $100 \%$ ethyl alcohol for $10 \mathrm{~min}$ and stored at least for an overnight before staining. For staining, slides were rinsed in distilled water, covered with $30 \mu \mathrm{L} 1 \mathrm{X}$ ethidium bromide staining solution, and protected with a coverslip. The material was evaluated immediately at $400 \mathrm{X}$ magnification using a fluorescence microscope (Olympus) with a 515-560-nm excitation filter and a 590-nm barrier filter. All experiments were performed three times and in duplicate.

The extent and distribution of DNA damage indicated by the single-cell gel electrophoresis assay were conducted by examining at least 100 randomly selected and nonoverlapping cells (50 cells per coded slide) per culture well in a blind analysis. These cells were scored visually, according to tail size, into the following 4 classes: class 0 - no tail; class 1 - tail shorter than the diameter of the head (nucleus); class 2 - tail length 1 to 2 times greater than the diameter of the head; and class 3 - tail length more than twice the diameter of the

Genetics and Molecular Research 16 (3): gmr16039700 
head. Comets with no heads with nearly the entire DNA in the tail or with a wide tail were excluded from the evaluation because these probably represented dead cells (Hartmann and Speit, 1997). The total score for 100 comets, which ranged from 0 (no damage) to 3 (severe damage), was obtained by the sum of multiplying the number of cells in each class by the damage class on a scale of 0-300 arbitrary units.

\section{CBMN assay}

The CBMN assay was performed according to the protocol described by Fenech (2000). Two cell types, human PBL and HepG2 cells, were used in this protocol. Experiments were carried out in human PBL from two donors, made in duplicate, and in HepG2 cells made in triplicate. Cell culture was done in a $25-\mathrm{cm}^{2}$ flask and added different concentrations of the tested oil $(2.5,10,100,500$, and $1000 \mu \mathrm{g} / \mathrm{mL})$. Two different drugs were used as positive controls, $150 \mu \mathrm{M}$ MMS for the human PBL and $2 \mu \mathrm{M}$ benzo[a]pyrene for the HepG2 cells.

Whole blood samples $(0.4 \mathrm{~mL})$ were added to $5 \mathrm{~mL}$ culture medium supplemented with $10 \%$ fetal calf serum. PHA was added to each culture flask at $10 \mu \mathrm{L} / \mathrm{mL}$, and PBL were incubated at $37^{\circ} \mathrm{C}, 95 \%$ air and $5 \% \mathrm{CO}_{2}$ in a humidified incubator for $72 \mathrm{~h}$. Forty-four hours after starting PBL culture, the human PBL were exposed to different concentrations $(2.5,10$, 100,500 , and $1000 \mu \mathrm{g} / \mathrm{mL}$ ) of EOO. Four hours after test compound addition, cytochalasin-B $(6 \mu \mathrm{g} / \mathrm{mL})$ was added to each culture. The cells were harvest by centrifugation ( 5 min at 850 $g$ ), and pellets were resuspended in a chilled hypotonic solution of $0.075 \mathrm{M} \mathrm{KCl}$ for $5 \mathrm{~min}$. Subsequently, cells were washed once with $5 \mathrm{~mL}$ cold methanol:acetic acid solution (3:1) $(\mathrm{v} / \mathrm{v})$. The fixation procedure was applied three times. Formaldehyde $(1 \%)$ was added to the last fixative to preserve the cytoplasm. The cell suspension was placed onto slides and stained with a solution of 5\% Giemsa dye in phosphate buffer $(\mathrm{pH} 6.8)$ for $5 \mathrm{~min}$.

For micronucleus test using HepG2 cells, cells had been grown for one complete cell cycle $(24 \mathrm{~h})$ and treated for $24 \mathrm{~h}$ with the test compound. Then, the cells were washed, harvested and incubated again with cytochalasin B for $28 \mathrm{~h}$. After this period, the same protocol described above to PBL was performed.

Following standard criteria (Fenech, 2000), micronucleus analysis was performed on coded slides by scoring 1000 binucleated cells for each culture flask. For the analysis, an optical microscope (Zeiss, Primo Star) at 100X magnification was used. As a measure of cytotoxicity, the nuclear division index (NDI) was calculated following the formula: NDI $=[\mathrm{M} 1+2(\mathrm{M} 2)+3(\mathrm{M} 3)+4(\mathrm{M} 4)] / \mathrm{N}$, where M1-M4 indicate the number of cells with 1-4 nuclei as assessed in 500 cells $(\mathrm{N})$ (for each culture).

\section{Statistical analysis}

The data obtained in the comet assay and CBMN (with HepG2 cells) were submitted to analysis of variance (ANOVA) and Tukey-Kramer multiple comparison tests, and the data obtained from the CBMN assay (with lymphocytes) were analyzed by the Student $t$-test, both using the GraphPad Prism ${ }^{\circledR}$ software (version 5.02). A value of $\mathrm{P}<0.05$ was considered statistically significant for all the parameters evaluated.

\section{RESULTS AND DISCUSSION}

E. oleracea Mart. is a botanical species that is widely used as food and its fruit,

Genetics and Molecular Research 16 (3): gmr16039700 
known as açaí berries, presents considerable potential for the development of new medicines, being therapeutically used by rural inhabitants especially in Amazon region (Calvazara, 1972; Rodrigues et al., 2006). Our literature review showed that there are no previous studies involving the in vitro assessment of the genotoxic or antigenotoxic effects of EOO.

In the present study, we used an MTT assay to evaluate the cytotoxicity of EOO. The assay is based on the fact of the tetrazolium salt (MTT) is cleaved only in living cells with active mitochondria that can be read on a scanning multiwell spectrophotometer (Mosmann, 1983). Figures 1 and 2 show the results obtained by this test using lymphocytes and HepG2 cells, respectively. The concentrations of EOO tested were $0.1,0.5,1,2.5,5,10,25,50,100$, $250,500,800$, and $1000 \mu \mathrm{g} / \mathrm{mL}$, and the results after 4- and 24-h exposure to EOO showed that none of the tested concentrations induced cytotoxic effects in both cell types analyzed (cell viability was above $80 \%$ ).

A

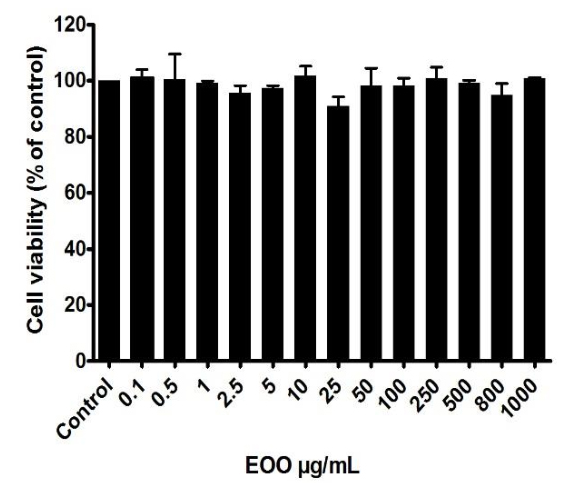

B

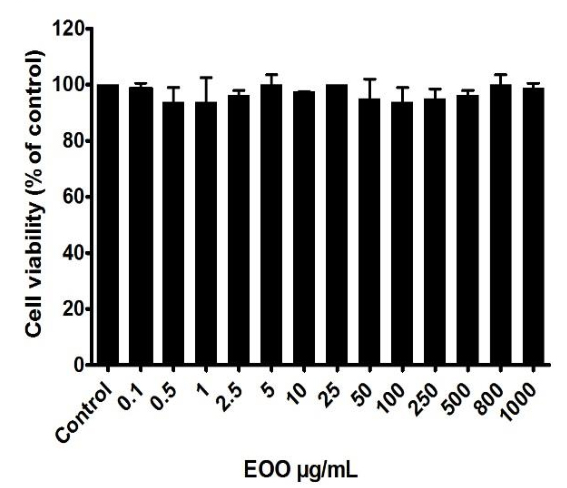

Figure 1. Cell viability based on the colorimetric MTT assay in human lymphocytes exposed to different concentrations of Euterpe oleracea oil (EOO) for 4 and $24 \mathrm{~h}$.

A

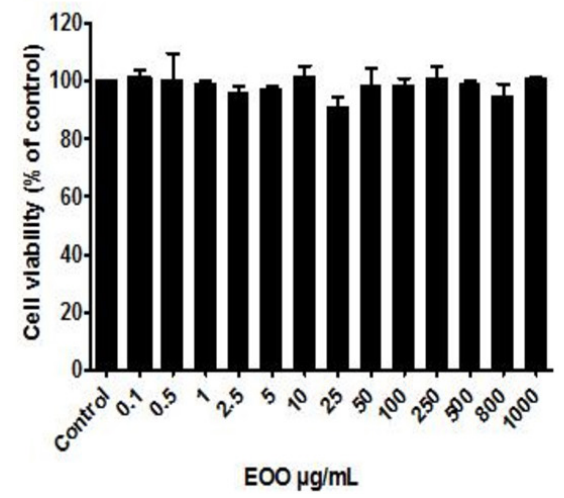

B

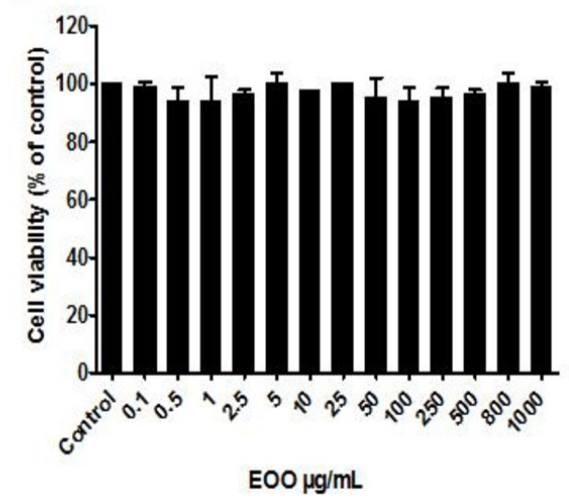

Figure 2. Cell viability based on the colorimetric MTT assay in HepG2 cells exposed to different concentrations of Euterpe oleracea oil (EOO) for 4 and $24 \mathrm{~h}$. 
Dias et al. (2014) evaluated the cell growth inhibition of açaí polyphenolic extract against colon cancer HT-29 and SW-480 cells and observed that $50-200 \mu \mathrm{g} / \mathrm{mL}$ of the extract inhibited the growth of SW-480 cells preferentially, without toxicity in the non-malignant CCD-18Co colon fibroblast cells. The mechanisms involved in this cell growth inhibition included downregulation of pro-oncogenic-specific proteins.

On the other hand, Silva et al. (2014) observed that bark, seed, and total açaí fruit hydroalcoholic extracts showed cytotoxicity (and antitumorigenic potential) in the human breast cancer cell line (MCF-7), but not in colorectal adenocarcinoma cells, also by using the MTT assay. The differences in the extract composition, protocols, and cell types analyzed could explain the differences in the cytotoxic effects observed in these two studies between themselves and our present study.

Choosing five concentrations of the results mentioned above with MTT assay, we assess the genotoxic and antigenotoxic property of EOO by the comet assay. The alkaline version of the comet assay detects low levels of DNA damage, including breakage of singlestranded and double-stranded DNA, alkali-labile sites, and DNA-DNA and DNA-protein crosslinks (Tice et al., 2000). The results obtained for genotoxic evaluation of EOO in human PBL and HepG2 cells are shown in Figures $3 \mathrm{~A}$ and 4A, respectively. The cell viability of both cells at all concentrations was greater than $85 \%$ using trypan blue staining, which confirms the absence of cytotoxicity observed by the NDI in the CBMN. For the five concentrations tested, none of the two cell types tested showed a significant increase in the scores of the DNA damage compared to the negative control. A significant increase in DNA damage (scores) on both cell types was observed only for a positive control MMS, indicating the validity of this test in the detection of genotoxic effects. The antigenotoxic assessment showed a nonsignificant reduction in the extent of DNA damage for both cell types exposed to the five concentrations of EOO plus MMS, compared with the MMS-treated culture alone (Figures 3B and 4B), indicating the absence of chemopreventive effects of EOO against MMS.
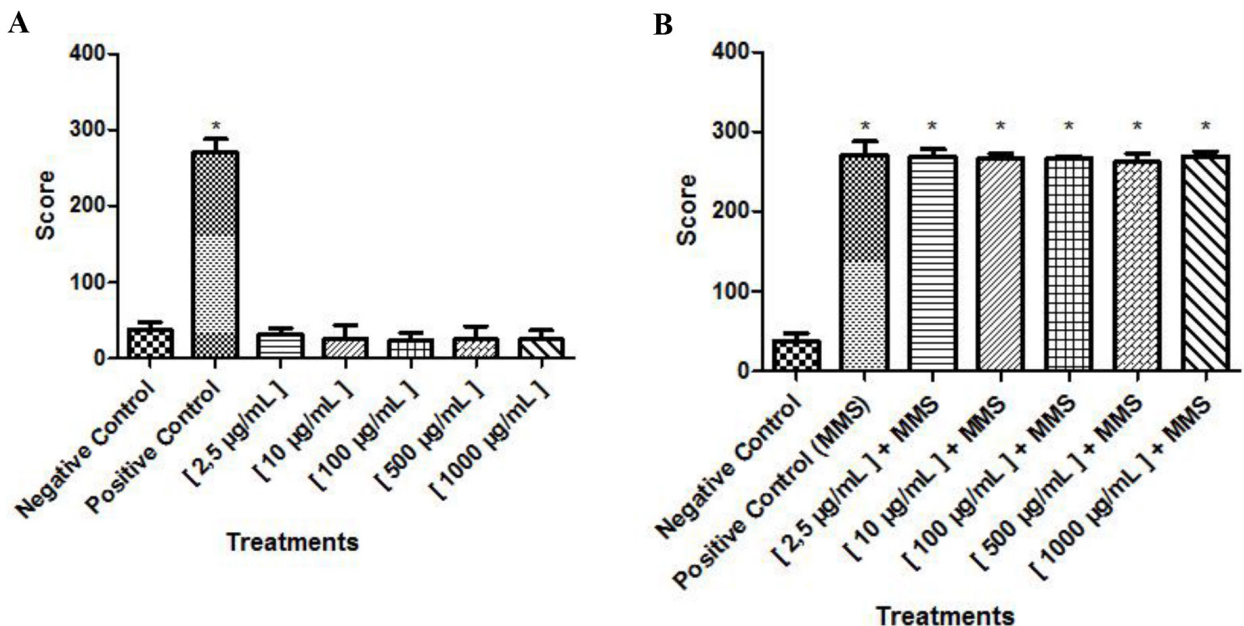

Figure 3. Genotoxicity (A) and antigenotoxicity (B) of Euterpe oleracea oil (EOO) in culture of human lymphocytes by comet assay. ${ }^{*} \mathrm{P}<0.001$ (ANOVA/Tukey post-test) when compared to negative control. Data are reported as mean values obtained from three independent experiments. Score $=$ DNA damage index.

Genetics and Molecular Research 16 (3): gmr16039700 
A

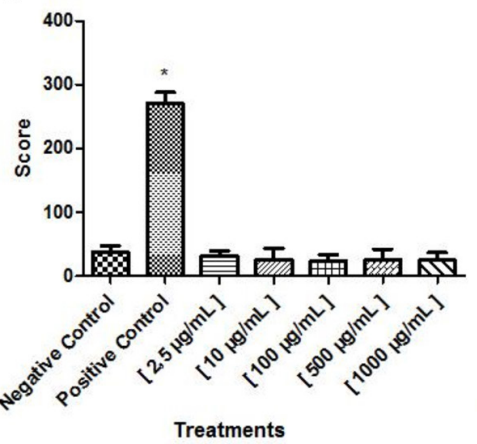

B

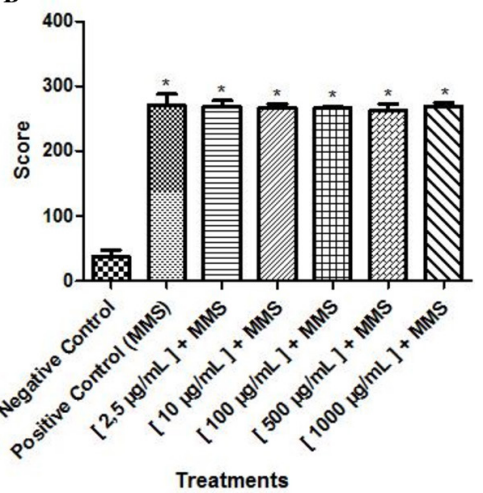

Figure 4. Genotoxicity (A) and antigenotoxicity (B) of Euterpe oleracea oil (EOO) in culture of HepG2 cells by comet assay. $* \mathrm{P}<0.001$ (ANOVA/Tukey post-test) when compared to negative control. Data are reported as mean values obtained from three independent experiments. Score $=$ DNA damage index.

The other endpoint evaluated in the present study was the capacity of the EOO to produce clastogenic/aneugenic effects in human cells in vitro by CBMN. This test is part of a series of test on genetic toxicology, and detect micronuclei in the cytoplasm of interphase cells, due to the formation of acentric chromosome fragments (clastogenic effect) or whole chromosomes that are unable to migrate to the poles during cell division (aneugenic effect) (OECD TG 487, 2014). Our results of clastogenic/aneugenic evaluation of EOO in PBL and HepG2 cells are provided in Tables 1 and 2. There were no statistically significant differences $(\mathrm{P}>0.05)$ in the mean number of binucleated cells with micronuclei between the negative control and the cultures treated with the five concentrations of EOO alone, indicating an absence of clastogenic/aneugenic effects of the tested oil. As expected, cell cultures treated with MMS or BaP (positive control) showed a high mean number of binucleated cells with micronuclei when compared to the negative control $(\mathrm{P}<0.001)$. Besides, cells cultured with different concentrations of EOO simultaneously with the positive control drugs did not lead to a significant reduction in the mean number of binucleated cells with micronuclei when compared with the flask cells cultured with MMS or BaP alone.

Table 1. Cytokinesis-block micronucleus (CBMN) assay in cultures of human lymphocytes treated with Euterpe oleracea fruit oil (EOO) and the respective controls.

\begin{tabular}{|c|c|c|c|c|}
\hline \multirow[t]{2}{*}{ Treatment $(\mu \mathrm{g} / \mathrm{mL})$} & \multicolumn{3}{|c|}{ Total No. in $1000 \mathrm{BN}$ cells } & \multirow[t]{2}{*}{ NDI } \\
\hline & $\mathrm{MNi}$ & NPBs & NBUDs & \\
\hline Vehicle control & $1.0 \pm 0.0$ & $0.0 \pm 0.0$ & $0.0 \pm 0.0$ & $2.02 \pm 0.01$ \\
\hline Positive control & $10.0 \pm 2.0^{*}$ & $3.0 \pm 1.0^{*}$ & $2.5 \pm 0.5^{*}$ & $2.22 \pm 0.05$ \\
\hline EOO $(2.5 \mu \mathrm{g} / \mathrm{mL})$ & $1.0 \pm 0.0$ & $0.5 \pm 0.5$ & $0.0 \pm 0.0$ & $2.16 \pm 0.00$ \\
\hline EOO $(10 \mu \mathrm{g} / \mathrm{mL})$ & $1.0 \pm 0.0$ & $0.0 \pm 0.0$ & $0.0 \pm 0.0$ & $2.17 \pm 0.01$ \\
\hline $\mathrm{EOO}(100 \mu \mathrm{g} / \mathrm{mL})$ & $1.0 \pm 1.0$ & $0.5 \pm 0.5$ & $0.0 \pm 0.0$ & $2.09 \pm 0.20$ \\
\hline $\mathrm{EOO}(500 \mu \mathrm{g} / \mathrm{mL})$ & $1.5 \pm 0.5$ & $0.5 \pm 0.5$ & $0.5 \pm 0.5$ & $2.20 \pm 0.09$ \\
\hline EOO $(1000 \mu \mathrm{g} / \mathrm{mL})$ & $1.5 \pm 0.5$ & $0.0 \pm 0.0$ & $0.0 \pm 0.0$ & $2.20 \pm 0.00$ \\
\hline $\mathrm{MMS}+2.5 \mu \mathrm{g} / \mathrm{mL}$ EOO & $10.5 \pm 0.5^{*}$ & $3.5 \pm 1.5^{*}$ & $2.0 \pm 1.0^{*}$ & $2.00 \pm 0.07$ \\
\hline MMS $+10 \mu \mathrm{g} / \mathrm{mL}$ EOO & $9.5 \pm 0.5^{*}$ & $3.0 \pm 1.0^{*}$ & $1.0 \pm 0.0^{*}$ & $1.99 \pm 0.07$ \\
\hline $\mathrm{MMS}+100 \mu \mathrm{g} / \mathrm{mL}$ EOO & $8.5 \pm 1.5^{*}$ & $3.5 \pm 1.5^{*}$ & $1.5 \pm 0.5^{*}$ & $1.92 \pm 0.18$ \\
\hline $\mathrm{MMS}+500 \mu \mathrm{g} / \mathrm{mL}$ EOO & $12.0 \pm 0.0^{*}$ & $3.5 \pm 0.5^{*}$ & $2.5 \pm 0.5^{*}$ & $1.80 \pm 0.20$ \\
\hline $\mathrm{MMS}+1000 \mu \mathrm{g} / \mathrm{mL}$ EOO & $11.0 \pm 2.0^{*}$ & $4.0 \pm 0.0^{*}$ & $1.5 \pm 0.5^{*}$ & $1.85 \pm 0.12$ \\
\hline
\end{tabular}

Values are reported as means $\pm \mathrm{SD}$. BN, binucleated cell; $\mathrm{MNi}$, micronuclei; NPBs, nucleoplasmic bridges; NBUDs, nuclear buds; NDI, nuclear division index; $\mathrm{N}=2$. Vehicle control, $0.5 \%$ dimethylsulfoxide; Positive control, 150 $\mu \mathrm{M}$ methylmethanesulfonate (MMS). Data are based on three independent experiments. * Significant different from the negative control $(\mathrm{P}<0.05)$.

Genetics and Molecular Research 16 (3): gmr16039700 
Table 2. Cytokinesis-block micronucleus (CBMN) assay in cultures of HepG2 treated with Euterpe oleracea oil (EOO) and the respective controls.

\begin{tabular}{|c|c|c|c|c|}
\hline \multirow[t]{2}{*}{ Treatment $(\mu \mathrm{g} / \mathrm{mL})$} & \multicolumn{3}{|c|}{ Total No. in $1000 \mathrm{BN}$ cells } & \multirow[t]{2}{*}{ NDI } \\
\hline & $\mathrm{MNi}$ & NPBs & NBUDs & \\
\hline Vehicle control & $8.3 \pm 0.4$ & $2.3 \pm 0.4$ & $10.3 \pm 0.4$ & $1.71 \pm 0.03$ \\
\hline Positive control & $28.6 \pm 1.2^{*}$ & $9.3 \pm 1.6^{*}$ & $16.6 \pm 1.6^{*}$ & $1.68 \pm 0.00$ \\
\hline $\mathrm{EOO}(2.5 \mu \mathrm{g} / \mathrm{mL})$ & $7.6 \pm 0.9$ & $5.6 \pm 2.6$ & $12.0 \pm 2.9$ & $1.69 \pm 0.02$ \\
\hline EOO $(10 \mu \mathrm{g} / \mathrm{mL})$ & $10.0 \pm 0.8$ & $1.3 \pm 0.4$ & $9.0 \pm 2.1$ & $1.66 \pm 0.08$ \\
\hline $\mathrm{EOO}(100 \mu \mathrm{g} / \mathrm{mL})$ & $9.3 \pm 1.2$ & $5.3 \pm 3.0$ & $9.0 \pm 2.4$ & $1.77 \pm 0.09$ \\
\hline $\mathrm{EOO}(500 \mu \mathrm{g} / \mathrm{mL})$ & $11.6 \pm 3.0$ & $5.6 \pm 2.8$ & $10.6 \pm 0.4$ & $1.73 \pm 0.02$ \\
\hline EOO $(1000 \mu \mathrm{g} / \mathrm{mL})$ & $8.6 \pm 2.0$ & $5.0 \pm 2.1$ & $10.3 \pm 3.2$ & $1.62 \pm 0.08$ \\
\hline $\mathrm{BaP}+2.5 \mu \mathrm{g} / \mathrm{mL} \mathrm{EOO}$ & $30.3 \pm 1.2^{*}$ & $9.0 \pm 1.4^{*}$ & $18.3 \pm 0.9^{*}$ & $1.64 \pm 0.08$ \\
\hline $\mathrm{BaP}+10 \mu \mathrm{g} / \mathrm{mL}$ EOO & $28.3 \pm 0.4^{*}$ & $8.6 \pm 1.2^{*}$ & $17.6 \pm 1.2 *$ & $1.81 \pm 0.08$ \\
\hline $\mathrm{BaP}+100 \mu \mathrm{g} / \mathrm{mL}$ EOO & $28.3 \pm 1.6^{*}$ & $9.0 \pm 0.8^{*}$ & $18.0 \pm 1.4^{*}$ & $1.65 \pm 0.04$ \\
\hline $\mathrm{BaP}+500 \mu \mathrm{g} / \mathrm{mL}$ EOO & $28.6 \pm 1.2^{*}$ & $9.3 \pm 1.2 *$ & $19.6 \pm 1.8^{*}$ & $1.71 \pm 0.03$ \\
\hline $\mathrm{BaP}+1000 \mu \mathrm{g} / \mathrm{mL}$ EOO & $30.3 \pm 2.4^{*}$ & $9.3 \pm 0.9 *$ & $19.3 \pm 0.9^{*}$ & $1.72 \pm 0.08$ \\
\hline
\end{tabular}

Values are reported as means $\pm \mathrm{SD}$. BN, binucleated cell; MNi, micronuclei; NPBs, nucleoplasmic bridges; NBUDs, nuclear buds; NDI, nuclear division index; $\mathrm{N}=2$. Vehicle control, $0.5 \%$ dimethylsulfoxide; Positive control, $2 \mu \mathrm{M}$ benzo[a]pyrene (BaP). Data are based on three independent experiments. *Significant different from the negative control $(\mathrm{P}<0.001)$.

The in vitro results obtained in the present study by using the comet and CBMN assays confirm the results of in vivo studies reported by Marques et al. (2016). These authors investigated the genotoxicity of this same EOO in leukocytes, liver, bone marrow, and testicular cells of Wistar rats, after 14 consecutive days of treatment, and also observed that EOO presented no significant DNA damage in the cells analyzed. Similar results were also observed for the genotoxic evaluation of E. oleracea fruit pulp extract, when Ribeiro et al. (2010), also after treating mice during 14 consecutive days, reported the absence of genotoxic effects of açaí pulp in mouse bone marrow, liver, and kidney cells, by using micronucleus and comet assays.

Schauss et al. (2010) evaluated the safety of an açaí-fortified fruit and berry functional juice beverage (MonaVie Active ${ }^{\circledR}$ ) done in vivo and in vitro using some tests to analyze of genotoxicity and mutagenicity. MonaVie Active ${ }^{\circledR}$ was negative for mutagenic effects of the bacterial reverse mutation assay, the chromosomal aberration assay, the mammalian cell mutation assay (L5178Y), and the in vivo micronucleus study. However, the toxicological evaluation of Euterpe edulis, which can be considered a superfruit, showed positive mutagenicity results detected by Salmonella typhimurium TA97 strain (AMES test) at low doses, as well as positive results that were also obtained for the mammalian erythrocyte micronucleus assay (Felzenszwalb et al., 2013). The authors concluded that the pulp of E. edulis contains compounds with the capacity to induce mutagenicity and clastogenic/aneugenic effects.

The antigenotoxic assessment of açaí oil and açaí pulp showed different results. In the present study, we observed that açaí oil did not present chemoprevention against the DNA damage induced by MMS and BaP. However, Ribeiro et al. (2010) observed protective effects of açaí pulp in cells of mice of an in vivo experiment, in both acute and subacute treatments, when administered before doxorubicin. On another study, da Silva Santos et al. (2014) observed that methanolic extract of açaí fruit protects astrocytes against manganese neurotoxicity, but at high concentrations, the "pro-oxidant" effects of its constituents likely prevail. The differences of the antigenotoxic potential observed could be due to the difference in the in vitro and in vivo designed experiments, due to different DNA damage agents used, due to differences in the chemical constituents of açaí pulp and açaí oil, and due to a combination of these factors.

Genetics and Molecular Research 16 (3): gmr16039700 
The chemical constitution of the E. oleracea fruit pulp and the E. oleracea fruit oil is not identical. Açaí pulp presents carotenoids, anthocyanins, phenolic acids, and flavonoids (Ribeiro et al., 2010). Açaí oil presents polyphenols, fatty acids (vanillic acid, palmitic acid, $\gamma$-linolenic acid, linoleic acid, and oleic acid), phenolic acids (cinnamic and caffeic acids), flavonoids (quercetin and kaempferol rutinoside), and other acids identified as protocatechuic acid, ferulic acid, and syringic acid (Marques et al., 2016). The data obtained in the present study and the data available in the literature indicate that açaí oil and açaí pulp, despite some differences in the chemical constitution, did not present genotoxic effects. However, its antigenotoxic assessment showed different potentialities and needed to be better investigated in further studies.

In conclusion, under the experimental conditions employed in the present study, we observed by the comet assay and by the cytokinesis-block micronucleus test that the fruit oil of E. oleracea is not genotoxic or clastogenic/aneugenic in cultured human lymphocytes and HepG2 cells. Besides, this tested oil did not present chemopreventive effect against the genotoxicity of MMS and $\mathrm{BaP}$ in the simultaneous treatment protocol. However, we think that further studies are needed to better assess the antigenotoxic potential of the açaí fruit oil, due to its phytochemical composition with antioxidant constituents and positive chemoprevention observed in açaí pulp.

\section{Conflicts of interest}

The authors declare no conflict of interest.

\section{ACKNOWLEDGMENTS}

Research supported by FAPESP - Fundação de Amparo à Pesquisa do Estado de São Paulo (Grant \#2012/17241-8), Brazil. E.S. Marques thanks CAPES for the PhD's degree scholarship.

\section{REFERENCES}

Bauer NC, Corbett AH and Doetsch PW (2015). The current state of eukaryotic DNA base damage and repair. Nucleic Acids Res. 43: 10083-10101.

Caetano RS, de Souza ACR and Feitozao LF (2014). O uso de plantas medicinais utilizadas por frequentadores dos ambulatórios Santa Marcelina, Porto Velho - RO. Rev. Saúde Pesqui. 7: 55-63.

Calvazara BBG (1972). As possibilidades do açaizeiro no estuário amazônico. Bol. Fac. Cienc. Agrar. 5: 165-230.

da Silva Santos V, Bisen-Hersh E, Yu Y, Cabral ISR, et al. (2014). Anthocyanin-rich açaí (Euterpe oleracea Mart.) extract attenuates manganese-induced oxidative stress in rat primary astrocyte cultures. J. Toxicol. Environ. Health A 77: 390-404. https://doi.org/10.1080/15287394.2014.880392

de Bem GF, da Costa CA, de Oliveira PR, Cordeiro VS, et al. (2014). Protective effect of Euterpe oleracea Mart (açaí) extract on programmed changes in the adult rat offspring caused by maternal protein restriction during pregnancy. $J$. Pharm. Pharmacol. 66: 1328-1338. https://doi.org/10.1111/jphp.12258

Dias MM, Noratto G, Martino HS, Arbizu S, et al. (2014). Pro-apoptotic activities of polyphenolics from açai (Euterpe oleracea Martius) in human SW-480 colon cancer cells. Nutr. Cancer 66: 1394-1405. https://doi.org/10.1080/0163 $\underline{5581.2014 .956252}$

Favacho HAS, Oliveira BR, Santos KC, Medeiros BJL, et al. (2011). Anti-inflammatory and antinociceptive activities of Euterpe oleracea Mart., Arecaceae, oil. Braz. J. Pharmacog. 21: 105-114.

Felzenszwalb I, da Costa Marques MR, Mazzei JL and Aiub CA (2013). Toxicological evaluation of Euterpe edulis: a potential superfruit to be considered. Food Chem. Toxicol. 58: 536-544. https://doi.org/10.1016/j.fct.2013.05.029

Genetics and Molecular Research 16 (3): gmr16039700 
Fenech M (2000). The in vitro micronucleus technique. Mutat. Res. 455: 81-95. https://doi.org/10.1016/S00275107(00)00065-8

Hartmann A and Speit G (1997). The contribution of cytotoxicity to DNA-effects in the single cell gel test (comet assay). Toxicol. Lett. 90: 183-188. https://doi.org/10.1016/S0378-4274(96)03847-7

Hewitt NJ and Hewitt P (2004). Phase I and II enzyme characterization of two sources of HepG2 cell lines. Xenobiotica 34: 243-256. https://doi.org/10.1080/00498250310001657568

International Union Against Cancer (UICC) (2008). The World Cancer Declaration - A call to action from the global cancer community. Available at [http://oia.cancer.gov/pdf/World_Cancer_Declaration_08.pdf]. Accessed January 2, 2016.

Leão RBA, Ferreira MRC and Jardim MAG (2007). Study of therapeutical use plants in municipality of Santa Bárbara do Pará, State of Pará, Brazil. Braz. J. Pharmacog. 88: 21-25.

Marques ES, Froder JG, Carvalho JCT, Rosa PCP, et al. (2016). Evaluation of the genotoxicity of Euterpe oleraceae Mart. (Arecaceae) fruit oil (açaí), in mammalian cells in vivo. Food Chem. Toxicol. 93: 13-19. https://doi.org/10.1016/j. fct.2016.04.018

Mosmann T (1983). Rapid colorimetric assay for cellular growth and survival: application to proliferation and cytotoxicity assays. J. Immunol. Methods 65: 55-63. https://doi.org/10.1016/0022-1759(83)90303-4

Murrieta RSS, Dufour D and Siqueira AD (1999). Food consumption and subsistence in three caboclo populations on Marajó Island, Amazônia, Brazil. Hum. Ecol. 27: 455-475. https://doi.org/10.1023/A:1018779624490

OECD TG 487 (2014). OECD Guideline for the testing of chemicals. In vitro mammalian cell micronucleus test. Available at [http://www.oecd.org/env/ehs/testing/TG487Oct2012updated29oct.pdf].

Plotkin MJ and Balick MJ (1984). Medicinal uses of South American palms. J. Ethnopharmacol. 10: 157-179. https://doi. org/10.1016/0378-8741(84)90001-1

Del Pozo-Insfran D, Brenes CH and Talcott ST (2004). Phytochemical composition and pigment stability of Açaí (Euterpe oleracea Mart.). J. Agric. Food Chem. 52: 1539-1545. https://doi.org/10.1021/jf035189n

Ribeiro JC, Antunes LMG, Aissa AF, Darin JDC, et al. (2010). Evaluation of the genotoxic and antigenotoxic effects after acute and subacute treatments with açaí pulp (Euterpe oleracea Mart.) on mice using the erythrocytes micronucleus test and the comet assay. Mutat. Res. 695: 22-28. https://doi.org/10.1016/j.mrgentox.2009.10.009

Rocco L, Mottola F, Santonastaso M, Saputo V, et al. (2015). Anti-genotoxic ability of $\alpha$-tocopherol and Anthocyanin to counteract fish DNA damage induced by musk xylene. Ecotoxicology 24: 2026-2035. https://doi.org/10.1007/ $\underline{\mathrm{s} 10646-015-1538-1}$

Rodrigues RB, Lichtenthäler R, Zimmermann BF, Papagiannopoulos M, et al. (2006). Total oxidant scavenging capacity of Euterpe oleracea Mart. (açaí) seeds and identification of their polyphenolic compounds. J. Agric. Food Chem. 54: 4162-4167. https://doi.org/10.1021/jf058169p

Schauss AG, Clewell A, Balogh L, Szakonyi IP, et al. (2010). Safety evaluation of an açai-fortified fruit and berry functional juice beverage (MonaVie Active(®)). Toxicology 278: 46-54. https://doi.org/10.1016/j.tox.2010.04.017

Silva DF, Vidal FC, Santos D, Costa MC, et al. (2014). Cytotoxic effects of Euterpe oleracea Mart. in malignant cell lines. BMC Complement. Altern. Med. 14: 175. https://doi.org/10.1186/1472-6882-14-175

Souza MO, Santos RC, Silva ME and Pedrosa ML (2011). Açaí (Euterpe oleracea Martius): chemical composition and bioactivity. Nutrire: Rev Soc Bras Alim Nutr =. J. Brazilian Soc. Food Nutr. 36: 161-169.

Tice RR, Agurell E, Anderson D, Burlinson B, et al. (2000). Single cell gel/comet assay: guidelines for in vitro and in vivo genetic toxicology testing. Environ. Mol. Mutagen. 35: 206-221. https://doi.org/10.1002/(SICI)10982280(2000)35:3<206::AID-EM8>3.0.CO;2-J

Vásquez SPF, de Mendonça MS and Noda SN (2014). Ethnobotany of medicinal plants in riverine communities of the Municipality of Manacapuru, Amazonas, Brasil. Acta Amazon. 44: 457-472. https://doi.org/10.1590/18094392201400423

World Health Organization (WHO) (2002). National cancer control programmes. World Health Organization, Geneva.

Genetics and Molecular Research 16 (3): gmr16039700 